\title{
Revisiting Latin American Media Democratisation Theories and the Populist Factor
}

\author{
Edmundo Bracho-Polanco \\ University of Westminster, London, United Kingdom, \\ e.brachopolanco@westminster.ac.uk
}

\begin{abstract}
This article deals with the following question: How can Latin American media and communication theories help explain the mediatisation of populism and democracy? The article has a twofold goal: a) it contributes to the study of media, populism and democracy in the context of Latin America; b) it aims to raise awareness outside Latin America about the richness of Latin American media and communication theory for the analysis of the mediation of populism and democracy. The article introduces and engages with a variety of theories from Latin America that deal with globalisation, dependency, cultural imperialism, hybridity, and mediation, and reviews their potentials for explaining the mediatisation of populism and democracy. Theories or models of globalisation, dependency and cultural imperialism, and hybridity and mediation are reviewed analytically, as are some of their core critiques as drawn from various strands of thought, with emphasis on incorporating elements of populism theory. As interest grows in both academia and the media towards the ways in which populism is shaping the social and political spheres in the West, partly encouraged by the recent surge of populist leaders in Europe and the United States, past and current experiences and evaluation of Latin American populism can be constructive in understanding the phenomenon and its implications for communication, media and culture. This study finds that, following political shifts in the twenty-first century, Latin American populism represents a paradigm that is articulated to an important degree through communicative specificities and which can add analytical rigor to competing media and communication theories in the region.
\end{abstract}

Keywords: communication and media theories, media democracy, populism, Latin America

\section{Introduction}

This article deals with the following question: How can Latin American media and communication theories help explain the mediatisation of populism and democracy?

The article has a twofold goal: a) it contributes to the study of media, populism and democracy in the context of Latin America; b) it aims to raise awareness outside Latin America of the richness of Latin American media and communication theory for the analysis of the mediation of populism and democracy.

The article introduces and engages with a variety of theories from Latin America that deal with globalisation, dependency, cultural imperialism, hybridity, and mediation, and reviews their potentials for explaining the mediatisation of populism and democracy.

Various authors have highlighted Latin America's own richness in communication and media analysis and the ways in which its critical traditions have contributed to amplify the debate in media, cultural production, and democracy (Aguirre and Bisbal 2010; de Albuquerque 2019), as a general current committed to "progressive politics and the foundational principle of praxis as intrinsic to academic work" (Murphy and Rodríguez 2006, 268). 
In more than one way, Latin America represents a pioneering region in the development of media experience, models and theories, which have at various stages criticised, complemented or reinterpreted Western views (Retamozo 2006; Beltrán 2008; Barranquero 2011), particularly in their elaboration of guidelines by which to link communication and media praxis to plural access, participation, and social change. Aguirre and Bisbal argue that the study of communication and media in the region has been characteristically non-linear in its development, but "highly competitive and polemical", with different authors drawing in an eclectic manner from different currents of thought $(2010,11-12)$. Broadly speaking, these studies have been concerned, according to Beltrán (2008), Aguirre and Bisbal (2010), Leetoy (2016), and Barranquero and Sáez Baeza (2017), with media democratisation and policies; social transformation; globalisation and the state; definitions of cultural identity; and normative ideals of media practice.

This article first introduces Latin American Media and Communication Studies as background (Section 2). It then discusses the concept of populism and how it can be characterised generally and in the context of Latin America (Section 3). The third section is followed by a review of three of the region's most prevalent theories globalisation (Section 4), cultural imperialism and dependency (Section 5), and hybridity and mediation (Section 6) - while also explaining some critiques of the abovementioned strands of thought. Importantly, each of the theories or models discussed is critically complemented by addressing central aspects of populism in relation to media and democracy, with the aim of underpinning the theories in question and enhancing the critical discussion about Latin America's media democratisation today.

\section{Background: Latin American Media and Communication Studies}

It is generally assumed that media and communication studies in Latin America began in journalism schools or workshops. As Fuentes-Navarro argues, before the early 1960 s in most countries of the region "studying mass media meant little more than studying journalism" (1991, 9). Historical and legal studies of the press - and of broadcasting to a lesser degree - were also prevalent during the 1940s and 1950s, with an absence of criteria, and lacking social context (Marques de Melo 1984, 4). This panorama began to change during the late 1950s and early 1960s, arguably due to the expansion of media in the region, and also as a result of the formal launching, in 1959, of the International Centre of Studies for Latin American Journalism and Communication, or CIESPAL, under the auspice of UNESCO (Fuentes-Navarro 1991; 1999).

If, at first, scholarly expectations during the 1950s in Latin American media and communication research was mainly focused on informative and opinion content produced or consumed in local contexts, there were signs that scholarly attention was beginning to be placed on critically evaluating "social and educational consequences" in media production and consumption (Aguirre and Bisbal 2010,13). Emphasis on the relationship of the media and potential socio-political changes, the expansion of media outlets and the diversification of publicity, and their broader association with Latin American ideals of modernisation were situating media and communication studies and theoretical models under the scholarly umbrella of the social sciences. At this stage, the impulse offered by UNESCO in amplifying national media networks and promoting the scholarly development of media research was instrumental in the region (Fuentes-Navarro 1991; Marques de Melo 1984). The creation of CIESPAL spurred an institutional model to promote media research as an integral part of schools of science 
of communication and information, instead of as "extensions of schools of journalism" (Fuentes-Navarro 1991, 10).

It was arguably during the CIESPAL Conference of 1973 that an overarching vision of the development of research in media and communication in countries of the region was first discussed - this included discrepancies between some competing theoretical and methodological approaches (Aguirre and Bisbal 2010, 19). Many of these perspectives were informed to varying degrees by models of the Anglo-American sphere, such as in the works of Paul Lazarsfeld, Elihu Katz, Marshall McLuhan, Walter J. Ong, and Stuart Hall, among others. Yet important contributions were formulated during the 1970s by Latin American scholars such as Paulo Freire, pioneer in radical pedagogy; Luis Ramiro Beltrán, innovator in alternative communication and policies; leading regional communicologist and audience researcher Antonio Pasquali; theorist of communication and semioanthropology Eliseo Verón; Mario Kaplún, a promoter of transformative education and communication; author and researcher in regional media and policy Rafael Roncagliolo; critical theorist in communication and counterhegemony Armand Mattelart; and media historian and researcher Fernando Reyes Matta, among others.

This broad array of authors presented diverse and often contrasting communicational conceptualisations and practices in the context of Latin America, taking into account social transformation and democratisation processes which parts of the region were experiencing (Aguirre and Bisbal 2010; Prieto-Castillo 2019). By the early 1980s and during the 1990s, partly supported by the newly-founded Latin American Federation of Associated Mass Media Faculties (FELAFACS) and as the "globalisation debate" gained significance in the region, authors such as critical and counter-hegemony theorists Armand Mattelart and César Bolaño; regional democratisation theorist José Marques de Melo; cultural theorists Jesús MartínBarbero, Néstor García Canclini, and Guillermo Ortiz; media consumption researchers Marcelino Bisbal and Jesús Aguirre; and media discourse analysts Eliseo Verón and Ariel Dorfman, among others, had solidified various media and communication research approaches in diverse theoretical traditions, as part of the social sciences, which - according to studies (Aguirre and Bisbal 2020) - developed into influential models in the region and became subject to review during the twenty-first century (Fuentes-Navarro 1999; Prieto-Castillo 2019).

While some of these new studies were developed as a response to the 'globalisation debate' focusing on audience tactics in media consumption and appropriation - influenced to an important degree by the works of Michel de Certeau, Umberto Eco, and Manuel Martín Serrano - a heterodox Marxist theoretical approach helped to underpin the elaboration of a set of critiques centred on the economic and political conditions of communication flow and content, media ownership, counterhegemonic media discourses, and forms of resistance to media globalisation and transnationalism (Aguirre and Bisbal 2010; Flew and Waisbord 2015). In this sense, it has been argued that two central critiques emanating from this strand of thought in Latin America are the dependency and cultural imperialism models (Osorio Tejeda 2007) - both of which are assessed in more detail in this article.

Another important critical trend to emerge in Latin America and to have established itself as influential in the region since the 1980s is that of hybridity and mediation. The group of scholars who promoted these views, conscious of the complexities of social mediations and strongly grounded in cultural studies, analysed the varying contexts and manners in which cultural identities were being reconfigured in Latin America's mediated societies (Galindo 2009). Here, the works of Jesús Martín-Barbero and 
Néstor García Canclini - both pioneers in Latin American media consumption studies and cultural theory - are central and mutually complementary in their approach to assessing local communicational processes, cultural and media industries and production, and popular culture. This culturalist trend - which is further explored in this article - borrowed ideas from Walter Benjamin, Stuart Hall, Raymond Williams, and Angel Rama, among other cultural critics of hegemony and capitalism. It was able to blur some existing boundaries in scholarly disciplines in Latin America when analysing media, cultural, and sociological phenomena.

Indeed, one could argue that by the end of the twentieth century three central trends of media and cultural studies and research in Latin America derived from the following critical strands: globalisation; cultural imperialism and dependency; and cultural theory with a focus on hybridity and mediation. These three focuses of media and communication theory are reviewed in the article at hand.

With the surge of populist movements and leaderships in much of the region during the twenty-first century, these analytical traditions could benefit from critically theorising the populist paradigm in order to address and discuss the media and communication characteristics and dynamics in Latin America in a more comprehensive manner.

This article argues that while it is pertinent to review various critiques to theories or models of globalisation, cultural imperialism and dependency, and hybridity and mediation in Latin America, an assessment of the region's populism and its paradigm retains pressing relevance today when evaluating core aspects of media cultures and democratisation in Latin America. Although academic studies addressing mainly rightwing populism in Europe and the US have emerged in recent times (Kazin 2016; Moffitt 2016; Morelock 2018), existing literature on the relationship between democracy and the media in Latin America tends to bypass the relevance of the populist paradigm and the resurgence of this form of configuring the political and social spaces in many of the region's nations (Edwards 2012; Mudde and Rovira Kaltwasser 2012; de la Torre 2016; 2017).

In order to explain the scholarly trends in globalisation, cultural imperialism, dependency, hybridity and mediation theories and models, and to address how these can be effectively underpinned by populism theories, it is necessary to first discuss the nature of populism and its various definitions emerging from different critical perspectives, and to review existing literature which assesses the mediatisation of populism and democracy in the context of Latin America.

\section{The Nature of Populism and the Case of Latin America}

Recent scholarly interest in populism has been prompted by the election of Donald Trump in 2016, the Brexit referendum, and the surge of the extreme right wing in Europe during the last decade (de la Torre 2017; Sengul 2019; Brown 2020). Even though a variety of studies have been carried out, less attention has been paid to populism's resurgence in Latin America and its impact on specific social factors. Also, for all its apparent global scope and presence, the phenomenon of populism has been studied mainly within the context of political science and political theory - with special focus on Western nations and elaborated by Western scholars - with scarce linkage to communication, media and local culture (Gidron and Bonikowski 2013; Moffitt 2016; Sengul 2019). In Latin America populism has been, according to de la Torre, a sui generis phenomenon which mixes "democratising and inclusionary promises, totalitarian aspirations, and authoritarian practices" $(2016,134)$. In order to understand populism in a comprehensive manner and in the context of Latin America, while 
establishing its relevance as a complementary theoretical and conceptual component when assessing media, communication, and democracy in the region, it is necessary to first describe and discuss the variety of approaches and paradigms that have been formulated to define it.

Populism is a contested and elusive concept, and different studies have elaborated a varied understanding of it (Ionescu and Gellner 1969; Weyland 2001; Laclau 2005; Panizza 2005; Arditi 2007; Villacañas 2015; de la Torre 2016). The work of Canovan (1981; 1999) can be a pertinent starting point to address some traits and characteristics of the phenomenon. In her studies, Canovan outlines various forms of populism, covering a sample of populist movements emerging in different historical periods and social contexts, from the rural radical - as would be the case of the Russian narodnischestvo - to the political persona of Argentina's twentieth-century leader Juan Perón (Taggart 2004). Arguably the only common theme across all the populism types established in her taxonomic effort is "a resort to appeal to the people and a distrust of elites" (Canovan 1981, 264). Yet from her conclusions it can be inferred that, because populism incorporates such a wide range of elements lacking a common core, it becomes very complex to define.

Similarly, Laclau argues that there exists no unique referent to populism, that it is essentially "a way of building the political" (2005, xi). He has stressed that populism does not mean a "type of movement identifiable with either a special social base or a particular ideological orientation" $(2005,117)$. Weffort, in a more prescriptive manner, formulates that the phenomenon can be defined as a political structure which relies on a loose institutional framework; with an "anti-liberal, nationalist, anti-oligarchical political orientation; an economic orientation of industrialist and nationalist traits; a multi-class social composition with a broad support from the popular and working classes" (quoted in Ansaldi 2007, 80).

Weffort's definition tends to highlight the notion of populism as an anti-democratic force per se. This formulaic elaboration is challenged by authors such as Laclau (2005; 2006), Lander (2008), Mudde and Rovira Kattwasser (2012; 2013), and Mouffe (2018). In this sense, Laclau argues that populism - as a means of building the political should be essentially understood as a "political logic" rather than as a type of political movement $(2005,117)$. He argues that such logic entails a subversive form of challenging - politically and socially - the status quo and as "a starting point for a more or less radical reconstruction of a new order" $(2005,177)$. Furthermore, it is within this reconstruction of the political that populism arguably has the potential to become a democratic force. It entails, Laclau formulates, an inclusionary and redemptive component in its ideology $(2005 ; 2006)$. This idea in part stems from the notion that populism can give a voice to groups that are disenfranchised or do not feel represented by the political establishment, and is flexible enough in its ideology "to include perceptions and needs of different constituencies" (Mudde and Rovira Kattwasser 2012, 154).

According to this view, populism manages to establish a dichotomy whose "two poles are necessarily imprecise [...] such as the people versus the oligarchy, toiling masses versus exploiters, and so on" (Laclau 2005, 18). As an ideology, it tends to emerge from "outside the party system" while often promoting a discourse of rupture with the status quo (Merino 2007, 88). Its reservation towards liberal representative democracy, however, does not prevent it from employing its 'formalities', such as holding elections between competitive parties in order to legitimise itself in power (Ansaldi 2007; Gidron and Bonikowski 2013; Retamozo 2016). Moreover, and contrary to the claim of some critics, leaders of a populist bent tend to regard themselves as 
agents for deepening democracy and social justice, in the sense that they claim to embody the "voice" of the people (Mudde and Rovira Kattwasser 2012; Villacañas 2015; Mouffe 2018). It could be argued, following Villacañas' formulation, that these leaders tend to understand the people as "a community constructed by means of a hegemonic operation based on conflict" (Villacañas 2015, 28).

While many theorists and researchers would agree with the idea that populism tends to represent a fracture with the status quo - nominally the elite - not many make a clear distinction between a left- and a right-wing ideology and discourse within populism (Mudde and Rovira Kattwasser 2012; Villacañas 2015; Sengul 2019). This is not the case for Mouffe (2018), who establishes a difference between left- and rightwing populism, articulated, as in Laclau's approach, from a non-essentialist perspective of democracy and populism. Mouffe's definition relies on her analysis of Western European political dynamics and assesses left-wing populism as a strategy to build the "political frontier between 'the people' and 'the oligarchy' [which] constitutes the type of politics" that can enhance democratic practice $(2018,5)$. It is noteworthy, as Gandesha (2018) explains, that the figure of "the people" under this perspective should be understood differentially in the manner in which it is constructed by the Left and the Right. In this sense, Left populism "defines 'the people' in relation to the social structures and institutions" that tend to prevent their aspirations for equality and popular sovereignty (Mouffe 2018, 63).

Another important argument in defining populism is that it is characterised by a tendency to foster a highly affectionate and emotional bond between the leader and the people (Seligson 2007; de la Torre 2010; 2016; Brown 2020). According to some views, this may lead to a form of democratic practice - or pseudo-democratic practice - in which all political and moral legitimacy falls in the hands of a charismatic leader, a supreme "strong man" - possibly a caudillo, to use the expression in Latin America's political tradition - who "relates directly to 'the people"' (Merino 2007, 68). This type of leader, according to some authors, can present authoritarian traits, which become evident in the way the leader tends to monopolise the political arena, to "do away with representative and judicial institutions" (Seligson 2007, 82), and restrict some freedoms, such as dissent and freedom of expression (Weyland 2001; Diamond 2002; de la Torre 2016). In this sense, media in populist environments often experience curbing or loss of freedom and of autonomy, and the imposition of censorship. Moreover, normative media ideals as upheld by the liberal tradition, such as systematic checks on state authorities, access to official data and sources, and deliberation of critical opinions, among others, tend to be undermined (McQuail 2005; Keane 2009; de la Torre 2010; 2016; Waisbord 2013a).

After evaluating the Latin American democratic experience and its history of populism, Keane elaborates a version of fringe democracy of populist character defined as caudillo democracy. It is a "variant of representative democracy" underscored by a "twisted type of republican oligarchy rooted in the people" led by powerful caudillos -historically the strongmen in Latin America - "who liked looking at themselves in the mirror of the people they dominated" $(2009,384)$. He argues that this system is a "mutant" form of representative democracy and that, ultimately, it is "democratic only in appearance" $(2009,384)$. The system has had a continuous historical presence in Latin America since the early nineteenth century. No other part of the world, argue Keane (2009) and de la Torre $(2010 ; 2016)$, has witnessed this phenomenon to such a degree of intensity as has Latin America.

Indeed, it has been argued that this tradition of strong and quasi-messianic leadership was continued by the likes of Lázaro Cárdenas, Getúlio Vargas and Juan 
Perón in the 1930s and 1940s; to then re-emerge during the twenty-first century in figures as ideologically diverse as Hugo Chávez, Alvaro Uribe, Rafael Correa, Evo Morales, and Jair Bolsonaro (Castañeda and Morales 2008; Frajman 2014; de la Torre 2016; Rovira Kattwasser 2018). It has been argued that this personalist leadership regardless of its varying ideological shades - tends to establish a relation between the President and the people "which tends to generate submission from the people towards the leader, with a disturbing result: turning citizens into an empty shell and distributive justice into an instrument of domination" (Arditi 2007, 43). Within this dynamic, media play a central role as tools of politisation and mobilisation in the hands of leaders, often presenting a propagandist slant.

Studies of liberal leanings often formulate that populism, in general, tends to promote a rupture of party democracy institutionalism - particularly those forms of populist movements led by a personalist figure (Schamis 2006; de la Torre 2010; 2016). Moreover, these views question whether populist leaders' political articulations can genuinely attain the correction of social inequalities, and whether they have done so in a consensual manner and within a framework that promotes democratic freedom and strengthens democratic institutions (Schamis 2006; de la Torre 2010; Brown 2020). Operating on the edges of liberal ideals, as Arditi maintains, "populism can thrive in political democracies while it morphs into something that can become its nemesis" $(2007,53)$. The dynamics of populist media, according to this view, tend to construct strategies through which to dismantle pre-existing forms of democracy while underpinning an antagonistic and polarising discourse of 'us' against 'them', 'the people' versus 'the elite', 'the nation' versus 'the empire', etc.

The manner in which some studies have associated populism with authoritarian leaders, demagogues or caudillos has been contended by various authors (Laclau 2005; 2006; Lander 2008; Retamozo 2016). Lander (2008) affirms that these views have failed to assume the transformative democratic role that populist regimes have played in many societies, particularly in Latin America. In many cases, Lander argues, populist systems have been able to integrate broad sectors of society and minorities that had been "excluded both under oligarchic regimes and in the liberal-democratic experience" (Lander 2008, 77). In a similar vein, Laclau claims that populism has been "denigrated [...] and linked to a dangerous excess of the masses" $(2005,19)$, particularly by neo-liberal thinkers; while Mouffe argues that the same neo-liberal views have not only become dominant over genuine democratic principles but have also expanded "oligarchization over equality" $(2018,18)$.

Under this perspective it is also argued that the most evident interconnection between populism and authoritarianism is to be found in radical right-wing political leaderships and movements. Here, authoritarianism is understood as a socio-political means to seek "social homogeneity through coercion" (Morelock 2018, xiv). Stuart Hall's work during the 1980s used the term "authoritarian populism" when assessing Thatcherism (1988). Yet a set of more current and comprehensive studies would place leaders such as Donald Trump, Marine Le Pen, Geert Wilders, and Viktor Orbán as more adequate representations of right-wing populism bearing authoritarian traits (Mudde and Rovira Kattwasser 2013; Morelock 2018; Mouffe 2018). Many of these leaders utilise the Manichean discourse of 'us' against 'them', specifying 'alien forces' - such as immigrants and ethnic minority groups - as the enemies of the 'native people' and as 'anti-nativist' elements that are supported by the pre-existing political elite. Narratives of nativism and nationalism - mostly in Europe - have been used strategically in the surge of right-wing populism of authoritarian features during the twenty-first century. This is, to an important degree, a by-product of the neoliberal 
policies that were dominant in the sphere of Euro-America during the 1980s and 1990s (Morelock 2018; Mouffe 2018). It could be argued that the leadership of Jair Bolsonaro in Brazil, for example, fits into this framework - albeit with local and caudillo-like characteristics (Rovira Kattwasser 2018).

The emergence of the populist radical right in Europe, according to Mudde and Rovira Kattwasser (2012; 2013), has mainly relied on divisive identity and cultural issues, and should be considered exclusionary. While identity has been playing an important role in the recent surge of Latin American populism of a leftist bent, it is material interest and redistribution that have mostly underpinned these movements in the region. Yet if it is to be argued that populism in Latin America can be considered inclusionary and emancipatory in many of its manifestations (Mudde and Rovira Kattwasser 2012; 2013), its problematic relationship with some core democratic values, as defined in liberal models, must also be acknowledged (2012; 2013; de Albuquerque 2019). Most conceptualisations of populism, in assessing the analytical complexity of the populist phenomenon, agree on this.

As mentioned earlier, Latin American media and communication theories and models can gain further conceptual vigour by evaluating aspects of the populism paradigm in the region. In the following section differing ideas and standpoints about globalisation theory are reviewed. Importantly, the overview of such a pervasive concept aims to draw attention to both Western perspectives on globalisation and those that have emerged with a focus on Latin America, while addressing the relevance of the theoretical complementarity of some key aspects of populism.

\section{Globalisation and the Weight of the State in Populism}

In order to assess how the populist paradigm might contribute to broaden the framework for analysing communication, media, and democracy in the region, it is most pertinent to consider the concept of and discussion around Latin America vis-à-vis globalisation theory. The latter has permeated much of the communication, cultural, and politico-economic debate; especially because globalisation tends to challenge the notion of sovereignty and decision-making of the nation-states of the region (Flew and Waisbord 2015).

There has been broad debate among authors in Latin America about the nature of globalisation and the ways it has been transforming the region's social, cultural and media landscape (Mattelart 1999; 2010; Pasquali 2007; Flew and Waisbord 2015). Globalisation has been interpreted as a process of social, economic, political and cultural linkage that goes beyond varying forms of integration of nation-states to become the emergence of a new socio-historical nexus which defines the world and the way to think about it (Martín-Barbero 2002b). It is a view shared by some Latin American theorists, and tends to represent a celebratory position towards potential communicational interconnectivity, promotion of diversity, social resistance, plural access in the media, and journalistic autonomy (García Canclini 1995; Curran and Park 2000; Flew and Waisbord 2015).

To a certain degree, the assumption by these authors that globalisation encompasses a potential platform for social and political power transformation is not too dissimilar from Giddens' formulation that globalisation, as a new stage of modernity, has "stretched" local modes, "extended" communicational exchange and "decentred" previous dominant forms of social integration (1990; Roblas Martín 2012).

However, Giddens' (1990) premise that globalisation is the result of an international shift inherent to modernity and its alleged decentred character has been challenged by authors such as Mattelart (1999; 2010), Bolaño (1999), Dos Santos (2002), and 
McChesney $(2000 ; 2007)$, who regard it as a process that maintains key traits of both dependency and imperialism, whereby the governments of post-industrialised powers and transnational corporations dictate 'global' economic and political policies, thus potentially modifying the cultural and media landscape of entire nations.

In a similar vein, Benhabib (2005), Ferrer (2007) and Pasquali (2007) argue that globalisation is framed within a hegemonic dynamic, ultimately functional to the interests of the economically dominant nations and to specific social groups within them, and tending not to lead 'periphery' nations to genuine global integration. They emphasise that a way for these countries to overcome relative political, economic and cultural dependency towards dominant nations is by strengthening national policies of democratic participation and social distribution, while also implementing effective regional integration strategies in media.

Through different elaborations in their respective works, García Canclini (1999) and Tomlinson (1999) contend that globalisation is not univocally a discourse of dominance from the "centre" to the "periphery", but a set of processes that encourage both homogenisation and fragmentation throughout the world. In doing so, as García Canclini (1999) argues while focusing on the case of Latin America, globalisation reorders social inequality and differences without suppressing them. He stresses, together with Martín-Barbero (2002a), that most globalisation theorists tend to vindicate integrationism and egalitarianism as inherent traits of globalisation, but fail to observe and analyse inequality, exclusion, and segregation as part of its nature.

In a critique of globalisation that seeks to draw for Latin America a normative framework in media, Beltrán (2008) argues that the dominant discourse of globalisation has stimulated another wave of media deregulation both intra- and internationally, thus undermining both state and communitarian policies for the media, and weakening the backbone of democratic communications. In his appraisal of the market-driven ideals that have allegedly underpinned the information society and its technophilia, he argues for "responsible" national and regional media policies and reforms that enhance democratic participation and social mobilisation (Beltrán 2008). Further critical stances in the region formulate that the negative consequences of globalisation of the media go beyond the exacerbation of deregulation - local and national identities are affected negatively and become decentred, while centres of economic and political power, mainly the United States, impose the flow of communication and of media production (Bolaño 1999; Mattelart and Mattelart 2005; McChesney 2000; 2007; Mattelart 2010).

Yet it is of note that, with the emergence of new forms of populisms in the region since the early 2000s, there have been important shifts in media regulation. There is evidence of use of varying forms of regulation imposed by local governments for both national and international media which in more than one way have defied the hegemony of the United States and other Western powers while also positioning the national state to compete with global media trends and centre-periphery flow of content. Indeed, during the 2000s, the left-leaning populist governments of Argentina, Bolivia, Ecuador, and Venezuela implemented national laws and regulations for the media, in contrast to the prevailing deregulation and market-led policies of the 1980s and early-1990s, leading to intense critiques from the liberal private sector (Bisbal 2005; Kitzberger 2012).

The latter aspect brings to the foreground the argument that, contrary to the views of Giddens $(1990 ; 1998)$ and other globalisation enthusiasts, who stress that nationstate systems are waning under the pervasiveness of globalisation, under the populist paradigm - very often underpinned by a sustained nationalist rhetoric - some populist governments in Latin America have been able to maintain a prominent role in society's 
power structure and in shaping the local media system (Roblas Martín 2012). In contradiction with the narratives of both the global market enthusiasts and the technodeterminists, the idea of the national community and of a communication system "of the people" - an important characteristic of populism - places the states and their leader as prevailing "markers of differences" (Curran 2002, 183).

The populist paradigm, by placing local leadership and the nation-state in a central social and political role, represents a challenge for globalisation as a force and for its promotion of homogenising media and cultural production (de la Torre 2010; Flew and Waisbord 2015). For not only can populist leaders use media in an intensive and personalistic manner, thus subverting normative liberal dynamics, they also tend to introduce a strategically-designed regulatory framework that promotes a nationalist and protectionist media agenda while aiming to socially mobilise 'the people' and minimise rivalling political expression in the media. These have been argued to be characteristics of Latin American populism that tend to be bypassed when assessing the region's dynamics between media and democracy from perspectives grounded on liberal globalisation theory.

As demonstrated, scholarly literature about globalisation is ample, complex, and has been further diversified in the context of Latin America. It could be argued that the dependency model and cultural imperialism have comprised two of the critiques of the globalisation paradigm - specifically when addressing the liberal understanding of its conceptualisation. These critical strands have had a robust development and a significant impact on media and communication debates in Latin America. There is some conceptual overlapping in their respective focuses, mainly because they have both been constructed within a counter-hegemonic and radical tradition. Both are reviewed in the following section, and are partly complemented with relevant notions of populism.

\section{The Dependency and Imperialism Models under a Shifted 'Periphery'}

Prior to the emergence of globalisation debate among scholars, and since the 1960s, the question of hegemony and the socio-cultural relationship between "centre" and "periphery" became central to Latin American critical discussion in many fields of the social sciences (Mattelart 1999; Dos Santos 2002; Murphy and Rodríguez 2006; Lozano 2007). In analysing the character of media and cultural hegemony in the region, many authors based their critique primarily in the dominance of Western models, but more specifically in the way the United States' media and their content flows unidirectionally in the region as a form of cultural imperialism and the ideological and social consequences of this dynamic. Drawing on the political economy of communication, this has been one of the key arguments of Latin American media analysts and theorists such as Armand Mattelart, Luis Ramiro Beltrán, Theotonio Dos Santos, Rafael Roncagliolo, Elizabeth Fox, César Bolaño, and Carola García Calderón (Beltrán 2005; 2008; Pasquali 2007; Roblas Martín 2012).

Arguably, the critical approach of Mattelart (2010; Mattelart and Mattelart 2005) provides a warning about the media dependency within Latin America and its supposed ideological domination by the United States. His work pays special attention to class struggle, while positioning the subject as a central historical element in the region's socio-political, economic, and cultural capitalist framework of exclusion and domination (Maldonado 2015). Arguably the most notorious of these standpoints is his refusal to interpret the media's social function as an exclusive derivation of the way in which ownership and social classes are structured (Bolaño 1999). Mattelart argues that the media can be used as a key instrument for emancipation and resistance. This, 
he suggests, should apply particularly to developing non-Western societies in their struggle to "oppose Western control and create indigenous news and entertainment media" (Mosco 2006, 94). Mattelart's research on Latin America has amalgamated the analysis of both national and international power structures, of ideological struggles in everyday life, with a formulation of proposals of "resistance to the dominant classes and to the imperialistic culture" $(1999,9)$. He observes that, although the paradigm of "cultural imperialism" - particularly that of the United States - has been caricaturised over the decades within an "uncritical globalised" ideal, it has relevance when appraising non-Western societies, in the sense that it foregrounds the discussion of participative democracy and media of "returning the voice to the people" (Mattelart 1999, 9-10) and fostering self-development collectively.

To illustrate this, Mattelart draws from his experience as government communications advisor in Chile (Mattelart 1999; Mosco 2006). He argues that the "ideological sanitary cordon" that the United States imposed on Latin America during the Cold War era led to the development of a critical awareness, on the part of Latin American theorists and policy-makers, of the transnational character of the media, the US-led hegemonic neo-liberal project, and the necessity to formulate changes within such an "asymmetric framework" (Mattelart 1999, 10). Aspects of this ideological order and US socio-political influence, some authors would argue, continue to be present in twenty-first century Latin America, to the extent that media discourse and practice can be considerably affected by this one-way dynamic (Mattelart and Mattelart 2005; Barrett et al. 2008; Maldonado 2015). Latin America as a whole, Dos Santos (2002) and Frank (2004) argue, has since the 1970s maintained a relation of economic and cultural subordination primarily to the United States, whose condition of "metropolis" imposes monopolistic power over its "satellites". Under this intensely asymmetrical political, economic, and cultural dynamic Latin American states, argues Dos Santos, are curtailed in their socio-cultural and communicational development and end up "being prisoners of foreign financial capital" (Dos Santos 2002, 23).

Scholars such as Andre Gunter Frank, Luis Ramiro Beltrán, Antonio Pasquali, Elizabeth Fox, Theotonio Dos Santos and Armand Mattelart argue that a structure of dominance, dependency and cultural imperialism has been maintained between a "centre" and a "periphery" - the former consisting of the developed neo-liberal economies and the latter of the "developing" and "underdeveloped" economies (Beltrán 1999; Lozano 2007; Roblas Martín 2012; de Albuquerque 2019). "Centre" and "periphery" have been structurally connected to each other, and "the condition for the prosperity of the developed was the misery and exploitation" of the developing or underdeveloped (Sparks 2007, 83). Importantly, the flow of communication between peripheral countries tends to be limited, according to this model, and it is in the interest of the dominant developed countries for this to be so in order to force the "periphery" into a market dynamic, which is essentially created by the transnational corporations and governments of Western powers, and led by the United States (Thussu 2000; Waisbord 2000; McQuail 2005).

One constant of both the dependency and imperialist models has been that the centre has been permeating the periphery with a unidirectional media flow, promoting - mostly in a non-direct way - the values, ideologies and broad cultural traits of the dominant market-led societies. Such dynamics, as Waisbord (2000; 2012) explains, tend to reinforce foreign domination and the weakening of national cultures. Another constant has been the idea that media that are built around the international power structures of capitalism "constitute obstacles rather than conduits for democracy" (Waisbord 2012, 52). 
A critical comment to both the dependency and cultural imperialism perspectives, and to the centrality of Western cultural dominance, is that new centres of media production have emerged since the 1990s - especially in Latin America - thus defying to some degree the communication power of the United States (Schiller 1991; Straubhaar 2015). Locally, countries such as Mexico, Colombia, Argentina, and Brazil in particular have been able to challenge Anglo-American cultural production with, for example, locally-produced telenovelas and local broadcast comedies leading the way (Straubhaar $1991 ;$ 2015). Yet some scholars would argue that, for example, the case of Brazil's telenovelas exportation represents a form of "reverse media imperialism" (Schiller 1991, 22). Others contend that the counter-flow and apparent nondependency of parts of Brazilian and other Latin American cultural and media industries ultimately mirror a "creolization of U.S. cultural products" $(1991,22)$ and have not been able to incorporate forms of production and of representation that would enhance local diversity and plurality, but domination instead - which is the essential trait of dependency and cultural imperialism (Straubhaar 2015).

The dependency model has been elaborated, in part, as a response to the developmentalist thesis of media and communication. The latter is arguably a product of Western attempts to integrate an international framework of communication into "an explanatory perspective on development" aligned with the political and economic interests of elite groups (Mosco 2006, 94). It emerged from a technological determinist narrative, and has been, at core, market-oriented. Under the Latin American developmentalist perspective, the media represent a key index of development (Mosco 2006) for the periphery nations and a resource by which democratic values of neoliberal models can be enhanced. Yet its first significant theoretical challenge emerged from Latin American scholars who played an active role during the 1970s in the debates of both the New World Information and Communication Order (NWICO) and the National Communication Policies debates (Bolaño 1999; Aguirre and Bisbal 2010). These debates represented an attempt to curb the power of unidirectional media flow, mainly through an international media regulatory framework and by way of media production exchange between non-Western nations.

Even though various Latin American and Western authors recognise the importance of the dependency model and the appraisal of a "imperialist hegemony", some have questioned the premises of its critique. Advocates of the cultural imperialism and dependency views fail to observe and assess the nuanced relation of power between the state and the local public sphere in developing media systems. Conclusively, it could be argued that the dependency and cultural imperialism approaches' main problem has been not conceding "sufficient autonomy to the political, which is fundamental to recognising and exploring divisions within states and markets, as well as differences across political regimes" (Waisbord 2000, 54). Moreover, Latin American studies of this trend - with an essentially economicstructuralist focus - have seldom analysed the manner in which these 'peripheral' nations - as interpreted in the dependency model - tend to fail in constructing stable forms of political organisation in their attempt to modernise and achieve ideals of progress or development as set by Western powers. This, as Weyland argues, leads to a "political vacuum" which tends to be filled or "held together by personalistic leaders" in the populist tradition (Weyland 2001, 5). In other words, the diagnosis of decline, stagnation or corruption under the dependency model calls for a radical change (Weyland 2001; Beltrán 2008) of progress, order and emancipation - all of which play into the hands of the populist political discourse and ideals of social mobilisation. 
Under the populist paradigm theorists place emphasis on the political centrality of the state, its leader, and its struggle to dominate national media systems. This perspective is also critical towards both the imperialist and the dependency models in their alleged reductionist formulation of the dynamics by which news and information flow from the 'great powers' to 'developing' nations, the way in which non-Western cultures are misrepresented in news in developed countries, the dominant form of media ownership in the hands of the elites, and the exclusion of popular and subordinate sectors of society in the media (Fox 1988; Cole 1996; Laclau 2005; Beltrán 2008; de Albuquerque 2019). Hence, in this assessment of populism the concepts of centre and periphery show a tendency to be strategically and discursively displaced to a framework that is equally binary but more confrontational and emancipatory in character: the "people" against the "elite", and the "nation" against the "empire". Nominally, "periphery" is replaced by "national sovereignty" and "centre" with "empire" as part of the dominant populist discourse and communication strategy (Laclau 2005; Moffit and Tormey 2014). Again, in the construction of this Manichean and anti-imperialist dynamic, it is crucial to re-evaluate the relation between the media and the national or internal policies in Latin American countries under populist rule.

In this context, a critique of the dependency and imperialist models from the populist paradigm can stem from the pervasiveness of an anti-imperialist and nationalist discourse - usually promoted by the personalistic leader - and from the anti-dependency implementations of new communications and media policies and reforms (Arditi 2007; Kitzberger 2012). This framework of laws and regulations tends to be anti-liberal in nature and was brought forward in some Latin American nations during the twenty-first century by leaders such as Chávez, Correa, Morales, and Fernández de Kirchner. It is worth pointing out that this wave of media reformism and reconfiguration of communicational policies cannot be extrapolated to every nation in the region under populist governance. Yet, it has been in the context of populism of varying shades that the state has achieved an important degree of control over national media content - mainly broadcast - and a stronger disassociation with the transnational systems, springing mainly from the United States (Waisbord 2013b, 134).

As discussed in this section, the logic and styles of populism in Latin America in recent times have spurred statism in media and cultural production, placed much weight on national policies for media and communication, and shifted the notions of transcultural media flow and cultural 'periphery' in the region. The latter are some central aspects that the imperialism and dependency models could incorporate in their critical evaluation of Latin American mediatisation of populism and democracy in order to enrich their analysis. In Section 6, this article reviews the nature and pervasive legacy of Latin American cultural studies, with emphasis on two theories which have proved to be instrumental in redefining notions of participation, resistance, and subversion of the public vis-à-vis mediated products and within culture in general these are the theories of hybridity and of mediations. Again, towards the end of the section it is explained how the above-mentioned critical strands could gain from the analytical accompaniment of aspects of democracy and populism theory.

\section{Hybridity, Mediation, and the Crisis of Autonomy in Populism}

Some Latin American scholars found cultural imperialism and the dependency model - and the underpinning of their critical political economy - somewhat deterministic and reductionist when assessing the character and dynamics of culture, media, and communications in the region (Galindo 2009). Their different analytical approach, they argue, should rely more on revising the multiple mediations within existing cultural 
matrixes and the various strategies of cultural and media production and consumption in the region without placing ideology at the forefront (Aguirre and Bisbal 2010). A group of scholars belonging to Latin American media and cultural studies has, since the late 1980s, spurred vigorous debate in the areas of media and cultural phenomena, while presenting a critique of other theoretical frameworks and models (Artz et al. 2006; Bisbal and Nicodemo 2010). Cultural theorists Martín-Barbero and García Canclini have arguably led this trend; and they contend that some dominant theoretical models in the region rely too much on a "structuralist sociological" view, pessimistic in their diagnosis of mass media, that tends to explain cultural and media dynamics essentially in the binary terms of centre-periphery relations.

In an analytical tenor influenced by the works of Walter Benjamin, Stuart Hall, John Fiske and their ideas of post-Gramscian hegemony and resistance, both MartínBarbero and García Canclini find that the argument formulating that the media function as agents of ideological dominance needs to be reassessed, because ultimately "the masses" possess significant levels of autonomy, and the manner in which these assimilate foreign and commercially-produced media contents derives to a large degree from their particular view of the world and their cultural backgrounds (MartínBarbero and Silva 1998; Curran 2002; 2011). In this sense, these formulations also act as a critical evaluation of globalisation and hegemony from a more multi-disciplinary stance.

Martín-Barbero and García Canclini question what appears to be a binary reading in neo-Marxist understandings of Gramsci's concept of hegemony. On the one hand, there is the fatalistic view that the dominated social classes are essentially passive and can only attain mobilisation from 'outside' forces. On the other, there is the radical view that the subaltern classes possess an unlimited capacity for defiance and for producing change (Martín-Barbero 1993; Bisbal and Nicodemo 2010). Yet, as expressed by Martín-Barbero, in the context of Latin America "not every assumption of hegemonic power by the underclass is a sign of submission and not every rejection is resistance" $(1993,76)$. Hence, under this view, not all aspects of cultural or media production respond to the logic of domination - these can be ambivalent and at times paradoxical. For instance, some alternative or community media seemingly entail traits of complicity or submission while simultaneously evidencing signs of subversion or resistance (Martín-Barbero 1993; Vassallo de Lopes 2018). This can be illustrated through the manner in which alternative or community media initiatives appropriate work-related technologies in an apparent effort to "enable local populations to subvert the dominance" of Western discourse and resist consumer ideology to a significant degree; yet are too often reluctant to deviate from established norms of Hollywood-style production and distribution or from "uncritical mimicry of familiar styles and genres" that belong to the mainstream Western media (Howley 2002, 14).

The approach to the cultural and media analysis of both Martín-Barbero and García Canclini emanates from the way their respective works have evaluated how modernity is produced in Latin America, the nature of the region's heterodox and diverse paths in modernity, and how Latin America's particular "peripheral modernity" relates to global capitalism and to dominant Western political, socio-cultural and media discourses (Martín-Barbero 2002a; García Canclini 1995; 2008; Szurmuk and Waisbord 2011). The Western discourse of modernity, argues Martin-Barbero, has always been "decentred" in Latin America, in the sense that it relates much less to European "Enlightenment doctrines and high culture aesthetic" than to the way in which mass education and cultural industries - particularly the media - have expanded in the region (2002a, 42-43). 
In his critique of the dependency model and cultural imperialism, Martín-Barbero questions the dichotomous scheme by which cultures and the media are understood and analysed, and insists that 'centre' culture and 'periphery' culture do not necessarily exist in opposition to one another, but rather relate to each other in a highly fluid and hybrid dynamic (1993). Ideology, class consciousness, identity and media power in Latin America, as Martín-Barbero (1993) and García Canclini (1995; 1999) independently formulate, need to be interpreted in the context of the hybrid nature of the region's cultural specificities and dynamics, with emphasis on 'popular culture' and 'mass culture' - from folk art and salsa music to telenovelas and community radio.

The shift of analysis that these cultural theorists represent has placed particular emphasis on observing and rescuing the category of "the people" and "the popular" from theorists who "identify the popular with the masses" (Schlesinger 1993, xii). Their views contend the notion - as held by some Marxist theorists - that popular culture is necessarily assimilated within class struggle. In this sense, García Canclini explains that popular cultures and audiences in the region "are not a passive or mechanical effect of the reproduction controlled by the dominators; they are also constituted by retaking their own traditions and experiences in the conflict with those who exercise hegemony, more than domination" $(1995,198)$.

Thus, even though popular cultures have been utilised and exploited within the neoliberal logic of the market, these have also been capable of subverting the market rationale in the way media contents are produced and in the manner audiences consume, re-process and re-make cultural and media products. One example of this is the alternative television channel Canal 4 TV Utopía, which began broadcasting illegally in Argentina during the early 1990s as a reaction to President Menem's "neoliberal consensus" and "privatisation policies": in TV Utopía, the audience participated as producers, audience members were able to create bricolage programming which included non-professional audio-visual material, and they were provided with an alternative platform of resistance and participation for the Buenos Aires community (Vinelli 2014, 122).

Among alternative media projects which have been subverting mainstream communication and top-down policies in Latin America from indigenous communities, the Oaxaca-based Centro Nacional de Video Indígena is a noteworthy example. Founded in Southern Mexico during the early 1990s, it originated as part of the central government's efforts to "construct 'a visual memory' that corresponded in unthreatening ways to Mexico's diversity"; yet indigenous video-makers, media producers, and activists used both the financial and technological resources supplied by the Mexican government "to construct forms of autonomy that redefined their community" and subverted the state's sociopolitical aims in its wishful portrayal of these minority groups by using video and audio-recording formats to revalorise their own identity and culture (Wortham 2004, 366-367).

It is particularly the aspects of hybridity and nuanced subversion in which popular cultures receive and consume media and cultural products where these Latin American cultural theorists place the centrality of their research (Schlesinger 1993; Szurmuk and Waisbord 2011). Furthermore, argues García Canclini (1995), it is mainly within the relation of popular cultures and modernity where the levels of democratisation of a society should be studied and evaluated.

In this sense, argues Martín-Barbero (1993), when assessing the relation between democracy, culture and media, a thorough approach to research would imply moving away from the conception that the media operate as a hegemonic tool of control by the powerful and that media consumption and reception tend to be passive. Instead he 
proposes that the analysis should focus on what he defines as "mediations" (Orozco 2002; 2008; Vassallo de Lopes 2014; 2018). According to Martín-Barbero, mediations are "a 'place' from which one can understand the interaction between the space of production and that of reception" (quoted in Vassallo de Lopes 2018, 52). Hence, what the media produces should not be considered exclusively a response to the requirements of the industrial system, but also to the requirements that emanate from the specificities of a cultural framework and ways of seeing (Vassallo de Lopes 2018).

Mediations should be understood both as a media and an extra-media operative concept, which constitutes a theoretical perspective of communication production, product, and reception (Orozco 2008; Vassallo de Lopes 2014; 2018). This notion of mediation derives from Martin-Barbero's view of communication phenomena from "the trinomial communication/culture/politics [...] from which he criticises the exclusivism and determinism of technological-informational, semiologic and ideological paradigms that have marked the history of communication studies in Latin America" (Vassallo de Lopes 2014, 5). According to this paradigm, it is through mediations that the discourses of the media - especially in the context of Latin America - tend to accommodate the growing urban movements, the region's specific melodramatic cultural vein, and the tradition of popular myth, to the point where audiences or consumers learn to recognise both the way in which they are represented and their collective identity within the media (White 1989; Martín-Barbero 1993; Orozco 2008).

Although Martín-Barbero argues that the imperialism paradigm and Marxist theory in general present significant epistemological difficulties when applied to Latin America's cultural context and dynamics, the notion of resistance and mediation set forth by the disenfranchised sectors of society as key counter-hegemonic actors can be aligned to Marxist-leaning principles of class struggle (Pedro-Carañana 2020). In this sense, the idea of mediations in Latin America - as formulated by Martín-Barbero and influenced by Walter Benjamin's understanding of popular culture - does not evaluate media as providing "totalitarian domination, but hegemony subjected to contradictions"; while also revalidating the Marxist-inspired notion of the people prompting "counter-hegemonic appropriation and re-configuration of communication messages and technologies" (Pedro-Carañana 2020, 244-251).

A critique to the notions of hybridity and mediation begins by arguing that too often Latin American cultural studies fail to sufficiently address issues that are pivotal to the relation between media and society, such as, for example, the reshaping of media industries through regulation, the power structure within the media, the style of political leadership, the connections between news organisations and political regimes, the use of the media as ideological tools, freedom of expression, social responsibility, plural representation - many of these aspects are characteristic of the new surge of populism in Latin America (Sarlo 2001; de la Torre 2010; Waisbord 2012). Furthermore, in assessing how media institutions operate, the changes "in journalistic practice, as well as production and performance across the media industries" is a critical issue in order to understand "the political and social dimensions of the media" (Szurmuk and Waisbord 2011, 22).

Importantly, in the context of Latin American populism the 'autonomy' and 'subversiveness' of 'the masses' - as the theorists of cultural hybridity and mediation understand it - are often undermined in the way personalistic populism is articulated. For all the claims of the populist state of potentially increasing egalitarian, participative, communitarian and counter-hegemonic forms of democracy and promoting social emancipation - according to a group of scholars (Laclau 2005) - in its more common strand in the region, populism tends to establish a statist, centralised, nationalist and 
personalistic form of communication and of representation (Panizza 2005; de la Torre 2016). Indeed, populists build "popular" organisations and are able to mobilise "the people" in both urban and rural contexts, but they can also aim to keep these "under tight personal control" (Weyland 2001, 15). Paradoxically, such control is partly imposed through persuasive communication tactics that tend to promote ideals of sovereignty, emancipation, and the rupture of the old status quo (Waisbord 2011; Moffitt and Tormey 2014); yet these tenets tend to become part of the construction of a new and anti-liberal status quo which can weaken the autonomy of the civil society and of popular cultures (Garretón 2006). Under such crisis of representation, it thus becomes relevant to reassess the formulation made by García Canclini and MartínBarbero that Latin American societies in populist environments are able to thrive in terms of organic bottom-up popular organisation and of autonomous agency.

Similarly, the notion of the 'centre-periphery' relation contextualised as a fluid and hybrid dynamic can become theoretically displaced under the populist paradigm. It could be argued that, although often Latin American populist leaders strengthen significantly national media systems and that these become less 'peripheral' in relation to the 'empire', in symbolic terms the 'centre' tends to become the persona of the leaders in the sense that they build a communicative framework in which they represent 'the people' - or the periphery - and direct 'the will of the people'; while they only in imaginary terms seem to eradicate the notions of centre and periphery. These are imaginary, as Arditi would argue, because "the people and their representatives claim to mirror images of one another and because they confuse their relation of virtual immediacy with an actual suspension of the distance between them" $(2007,66)$.

A central aspect that is worth re-evaluating in Latin American cultural studies is the notion of communicational fluidity and negotiation by the people or audiences. As Laclau argues, under the populist logic and through its discourse society tends to be divided in Manichean terms (2005; 2006). The antagonistic set up of an us-againstthem framework and the symbolic elaboration of an external enemy - generally exacerbated by the leader - leads to social and political polarisation (Laclau 2005; Panizza 2005; Bisbal 2009). In communication strategies and media content, nuance is usually lost while polarised or antagonistic views become prevalent and gradually deeply entrenched in the public discourse. Media, hence, operates as one of the most visible mirrors of polarisation, and audiences - or 'the people' - have hardly any negotiating agency vis-à-vis the binary mediated messages of rivalling camps. Communication fluidity, as formulated by García Canclini and Martín-Barbero, suffers in an environment dominated by dualistic and confronted political discourses, categories and performances. These authors, like most of those belonging to the Latin American culturalist trend, seldom assess the ways in which the interactions and negotiations between the popular and the elite, the ruled and the rulers develop under predominant forms of populism in the region, or how these affect patterns of cultural production and consumption.

Within the most prevalent modes of Latin American populism - as has been discussed in this article - a Manichean framework tends to be constructed multidirectionally by political leaders and polarising interest groups. This binary sociopolitical discourse and setting has the potential to affect the ways in which 'the people' negotiate, re-configure, and subvert mediatisation, communication, and cultural production and consumption. Latin American cultural theory, with a focus on hybridity and mediation, would enhance its critique of popular culture, media audiences and consumption, cultural resistance and negotiation - among other elements conceptualised in their theories - by further adopting the above-described features of 
populism. After discussing the critical strands of hybridity and mediation, the next and final section draws nuanced conclusions about the relevance in Latin American scholarship of the three theories reviewed in this study - globalisation, cultural imperialism and dependency, hybridity and mediation theories - and their potential in explaining mediatisation of populism and democracy by embracing relevant critical perspectives emanating from the latter.

\section{Conclusions}

The global re-emergence of populism has generated important shifts in the twenty-first century political landscape, and in communication and media dynamics. Latin America has arguably been the region where the populist phenomenon has experienced a more pervasive and sustained presence during the past two decades - with the surge of leftist leaders like Chávez, Correa, Morales, and Fernández de Kirchner; and the likes of Uribe, Añez, and Bolsonaro on the right-wing spectrum. This study reinstates that populism is a contentious concept and should not be understood only as a politicalideological construction within a fixed normative frame. In Latin America's past and present - as the vast majority of literature suggests - populism has represented a challenge for institutional or liberal democracy, the possibility or 'spectre' to derive in various forms of authoritarianism, but also a form to build the political with a strong potential for emancipation and inclusivity.

The different critical stances reviewed in this article demonstrate a surface agreement on the anti-elite and Manichean binary character of populism in Latin America, yet overall offer a diverse ontological condition to populism and different ways to analyse and measure the phenomenon (de la Torre 2010; Gidron and Bonikowski 2013). Importantly, this diversity in analytical approaches shows a nuanced understanding of populism in the region, in which not all cases are underpinned by statism and protectionist policies, personalistic or caudillo leadership, and clear-cut authoritarianism as constant features: as commonly argued by most liberal literature (Laclau 2006). Moreover, in addressing the variants of populist claims in the context of Latin America, the works of Laclau, Mouffe, de la Torre, Mudde, Rovira Kattwasser, and Villacañas are able to push forward the notion that populism has a rather "abstract" and "chameleonic" character and therefore, as argue Mudde and Rovira Kattwasser, it "can be left-wing or right-wing, organized in top-down or bottom-up fashion, rely on strong leaders or be even leaderless" $(2013,153)$. These authors - drawing on the works of Mouffe and Weyland - highlight that some perspectives on Latin American populism reveal its inclusionary discourse and practices, particularly in its left-wing manifestations; while the vast majority of studies on twenty-first century populism in Europe - assessing mostly right-wing leaderships and movements - observe an exclusionary character. These critical views are central when evaluating the relationship between populism, culture, communications, and democracy in the region studied.

Indeed, Latin America has had a rich tradition of populist leaders, movements and parties since the beginning of the twentieth century; and its contemporary populism "belongs to the strongest political actors" (Mudde and Rovira Kattwasser 2013, 156). Given populism's historical prevalence in the region and its impact on virtually all spheres of social, cultural, political, and economic interaction, this study finds that the populism paradigm serves as a highly relevant concept in critically complementing existing Latin American theories of communication and culture.

This article has highlighted the pertinence of further addressing populism when debating a set of competing theories of media, communication and democracy in the 
context of Latin America: firstly, by reviewing them in a conceptual vein; and secondly, by identifying how these theoretical constructs and models can be complemented and critically enhanced through various formulations of populism. Hence, in this article, prevailing theories of globalisation, of dependency and imperialism, and of cultural hybridity and mediation have been charted, particularly in the manner in which they articulate the relationships - and tensions - between culture, media, and democracy communication. Since the 1970s and 1980s, all three theories or models have established themselves in the region's critical scholarship as central when discussing the trajectory of its politics, culture, communication and media (Murphy and Rodríguez 2006; Aguirre and Bisbal 2010). Indeed, all owe some scholarly influence to Western studies and critical approaches and have not been linear or homogenous in their development, yet they have not only focused on one specific socio-cultural space that of Latin America - but have been able to establish their distinctive conceptual framework and identity. Importantly, these different theoretical developments - without establishing static scholarly frontiers - have been in constant dialogue and tension between themselves, thus broadening debate and theoretical foundations in media and cultural studies in the region (Szurmuk and Waisbord 2011). However, with the vigorous re-emergence of populism in Latin America in the twenty-first century, these theories and models should reconsider their ways of theorising society, media, communication, and culture.

As mentioned earlier, globalisation theory, the dependency model and cultural imperialism, and the concepts of hybridity and mediations have been complemented in this article with relevant analyses of populism, with the objective to underpin their rigor and enhance theoretical discussion.

In this sense, and summarising, globalisation and its critique should consider the weight of national communication regulations and some of the policies - not all - that Latin American populists have introduced during the twenty-first century; and how they have curbed, often to significant degrees, the exacerbation of deregulation and freemarket capitalist dynamics promoted by most advocates of globalisation. It could be argued that the most visible cases in the region in implementing such types of policies - originally with the aim to enhance social mobilisation, inclusionary participation, and popular democracy - have been Chávez in Venezuela, Fernández de Kirchner in Argentina, Morales in Bolivia, and Correa in Ecuador. Here, the examples of the centrality of the populist state and leadership defy to some extent the theoretical breadth of globalisation.

Similarly, this article finds that both the dependency and cultural imperialism models could gain theoretical enrichment by reviewing their delineations with added aspects of the populist paradigm. In this sense, the models' notion of 'periphery' in communication flow from the dominant Western 'centres' - mainly the United States should become more nuanced. This is because under populism the idea of 'national sovereignty' and the role of the state tend to be substantial and crucial. Also, the prevalent anti-liberal tendency of most manifestations of contemporary Latin American populism, often of a Manichean discourse - as formulated by Laclau (2005) - tend to build an anti-imperialist rhetorical style and ideology. In doing so, cultural dependency is restrained and communication strategies tend to be reconfigured towards forms that can be understood as emancipatory and anti-imperialist. It is worth pointing out that often populist stances are promoted and set forth by personalistic and hyper-mediatic leaderships which antagonise notions of liberal democracy and can lead to strong social polarisation - which the media actively exacerbate. 
The social and ideological polarisation that commonly emerges in the context of populism is a key aspect that Latin American cultural studies scholars should address when evaluating local cultural industries as well as notions of hybridity and mediation within local media audiences. Polarisation can considerably affect the concepts and dynamics of cultural negotiation, resistance, and subversion as understood by García Canclini and Martín-Barbero because, in essence, communication strategies and styles in populism tend to be framed in a Manichean binary manner. Also, when liberal and neo-liberal projects are undermined by populism's statism and its personalistic leadership, both the hybrid character of local cultures and their hybrid resistance become embedded in a different type of power structure that is not necessarily a market-driven one, as originally proposed by this type of culturalist trend. Lastly, and in a similar vein to what this article has already highlighted regarding the globalisation, dependency and imperialism perspectives, the concept of 'centre-periphery' as understood by this group of scholars would gain from being revaluated. Arguably, under the populism paradigm the 'centre' can shift - at least partially - from the traditionally dominant Western power to one represented more directly by an anti-elite leader whose discourse posits an inherent virtuousness of "the people" (Arditi 2007; de la Torre 2016).

To conclude, by operationalising aspects of the paradigm of populism within some of the most influential Latin American media and communication theories, this article finds that one can more rigorously define and discuss ways in which specific political, socio-cultural and economic factors affect political discourse and style, cultural negotiations and media dynamics, media professionals' and audiences' tensions in national contexts, power relations and hegemonic struggles, liberal notions of freedom, and radical ideals of rupture and inclusivity in the region. Future studies in Latin American media, communications, culture and politics should strive to gain a better understanding of populism's permeation of the region's societies and its relevance in contributing to broaden and enrich the regional debates about democratising communication and media.

\section{References}

Aguirre, Jesús M. and Marcelino Bisbal, eds. 2010. Prácticas y travesías de comunicación en América Latina. Caracas: Centro Gumilla.

Ansaldi, Waldo, ed. 2007. La democracia en América Latina: Un barco a la deriva. Mexico City: Fondo de Cultura Económica.

Arditi, Benjamín. 2007. Politics on the Edges of Liberalism: Difference, Populism, Revolution, Agitation. Edinburgh: Edinburgh University Press.

Artz, Lee, Steve Macek and Dana L. Cloud, eds. 2006. Marxism and Communication Studies: The Point is to Change It. New York: Peter Lang.

Barranquero, Alejandro. 2011. Rediscovering the Latin American Roots of Participatory Communication for Social Change. Westminster Papers in Communication and Culture 8 (1): 133-154.

Barranquero, Alejandro and Chiara Sáez Baeza. 2017. Latin American Critical Epistemologies toward a Biocentric Turn in Communication for Social Change. Latin American Research Review 52 (3): 431-445.

Barrett, Patrick, Daniel Chavez and César Rodríguez-Gavarito, eds. 2008. The New Latin American Left: Utopia Reborn. London: Pluto Press.

Beltrán, Luis Ramiro. 2008. Comunicación para la democracia en Iberoamérica: Memoria y retos de futuro. Perspectivas de la Comunicación 1 (1): 145-158.

Beltrán, Luis Ramiro. 2005. La Comunicación para el desarrollo en América Latina. Paper presented at the III Panamerican Congress on Communication, Buenos Aires, 12-16 July. 
Beltrán, Luis Ramiro. 1999. Políticas de comunicación en América Latina: ¿Una utopía realizable? Archipiélago: Revista Cultural de Nuestra América 4 (24/25): 35-37.

Benhabib, Seyla. 2005. The Claims of Culture: Equality and Diversity in the Global Era. Princeton: Princeton University Press.

Bisbal, Marcelino, ed. 2009. Hegemonía y control comunicacional. Caracas: Alfa.

Bisbal, Marcelino. 2005. Otros lugares para pensar la política: Consecuencias en la política de la mediación comunicativa. Anuario ININCO 12: 57-94.

Bisbal, Marcelino and Pasquale Nicodemo. 2010. Sensibilidad, medios y cultura: reflexiones desde el consumo cultural. In Prácticas y travesías de comunicación en América Latina, edited by Jesús M. Aguirre and Marcelino Bisbal. Caracas: Centro Gumilla.

Bolaño, César, ed. 1999. Economía política, comunicación y conocimiento. Tucuman: La Crujía.

Brown, John. 2020. Neoliberalization, De-democratization, and Populist Responses in Western Europe, the US, and Latin America. Critical Sociology: 1-15. https://doi.org/10.1177/0896920520927456

Canovan, Margaret. 1999. Trust the People! Populism and the Two Faces of Democracy. Political Studies 47 (1): 2-16.

Canovan, Margaret. 1981. Populism. London: Junction.

Castañeda, Jorge G. and Marco A. Morales, eds. 2008. Leftovers: Tales of the Latin American Left. New York: Routledge.

Cole, Richard, ed. 1996. Communication in Latin America: Journalism, Mass Media, and Society. Washington: Jaguar Books.

Curran, James. 2011. Media and Democracy. London: Routledge.

Curran, James. 2002. Media and Power. London: Routledge.

Curran, James and Myung-Jin Park, eds. 2000. De-Westernizing Media Studies. London: Routledge.

de Albuquerque, Afonso. 2019. Protecting Democracy or Conspiring Against It? Media and Politics in Latin America: A Glimpse from Brazil. Journalism 20 (7): 906-923.

de la Torre, Carlos. 2017. Trump's Populism: Lessons from Latin America. Postcolonial Studies: Culture, Politics, Economy 20 (2): 187-198.

de la Torre, Carlos. 2016. Populism and the Politics of the Extraordinary in Latin America. Journal of Political Ideologies 21 (2): 121-139.

de la Torre, Carlos. 2010. Populist Seduction in Latin America. Columbus: Ohio University Press.

Diamond, Larry. 2002. Thinking about Hybrid Regimes. Journal of Democracy 13 (2): 21-35.

Dos Santos, Theotonio. 2002. Teoría de la dependencia. Balance y perspectivas. Mexico City: Plaza y Janés.

Edwards, Sebastian. 2012. Left Behind: Latin America and the False Promise of Populism. Chicago: University of Chicago Press.

Ferrer, Aldo. 2007. Globalización, desarrollo y densidad: Un abordaje de la experiencia de América Latina. In La democracia en América Latina: Un barco a la deriva, edited by Waldo Ansaldi, 123-130. Mexico City: Fondo de Cultura Económica.

Flew, Terry and Silvio Waisbord. 2015. The Ongoing Significance of National Media Systems in the Context of Media Globalization. Media, Culture \& Society 37 (4): 620-636.

Fox, Elizabeth, ed. 1988. Media and Politics in Latin America: The Struggle for Democracy. Beverly Hills: Sage.

Frajman, Eduardo. 2014. Broadcasting Populist Leadership: Hugo Chávez and Aló Presidente. Journal of Latin American Studies 46 (3): 501-526.

Frank, Andre Gunder. 2004. The Development of Underdevelopment. In The Sustainable Urban Development Reader, edited by Stephen M. Wheeler and Timothy Beatley, 45-50. London: Routledge.

Galindo, Jesús. 2009. Comunicología, comunicación y cultura. Razón y Palabra 66. Accessed July 9, 2020. http://www.razonypalabra.org.mx/N/n66/actual/igalindo.html 
Gandesha, Samir. 2018. Understanding Right and Left Populism. In Critical Theory and Authoritarian Populism, edited by Jeremiah Morelock, 49-70. London: University of Westminster Press.

García Canclini, Néstor. 2008. Latinoamericanos buscando su lugar en este siglo. Buenos Aires: Paidós.

García Canclini, Néstor. 1999. La globalización imaginada. Buenos Aires: Paidós.

García Canclini, Néstor. 1995. Hybrid Cultures: Strategies for Entering and Leaving Modernity. Minneapolis: University of Minnesota Press.

Garretón, Manuel. 2006. Sociedad civil y ciudadanía en la problemática latinoamericana actual. In Ciudadanía, sociedad civil, y participación política, edited by Isidoro Cheresky, 145-159. Buenos Aires: Mino y Davila.

Giddens, Anthony. 1998. The Third Way. Cambridge: Polity.

Giddens, Anthony. 1990. The Consequences of Modernity. Cambridge: Polity.

Gidron, Noam and Bart Bonikowski. 2013. Varieties of Populism: Literature Review and Research Agenda. Working Paper Series, Weatherhead Center for International Affairs 13 (4): 1-38.

Hall, Stuart. 1988. The Hard Road to Renewal. Thatcherism and the Crisis of the Left. London: Lawrence \& Wishart.

Howley, Kevin. 2002. Communication, Culture and Community: Towards A Cultural Analysis of Community Media. The Qualitative Report 7 (3): 1-24.

Ionescu, Ghita and Ernest Gellner, 1969. Populism: Its Meanings and National Characteristics. New York: Macmillan.

Kazin, Michael. 2016. Trump and American Populism. Foreign Affairs 95 (6): 17-24.

Keane, John. 2009. The Life and Death of Democracy. London: Simon \& Schuster.

Kitzberger, Philip. 2012. The Media Politics of Latin America's Leftist Governments. Journal of Politics in Latin America 4 (3): 123-139.

Laclau, Ernesto. 2006. La deriva populista y la centroizquierda latinoamericana. Nueva Sociedad 205: 56-61.

Laclau, Ernesto. 2005. On Populist Reason. London: Verso.

Lander, Edgardo. 2008. Populism and the Left: Alternatives to Neo-Liberalism. In The New Latin American Left: Utopia Reborn, edited by Patrick Barrett, Daniel Chavez and César Rodríguez-Gavarito, 69-98. London: Pluto Press.

Leetoy, Salvador. 2016. Notas sobre modernidad, decolonidad y agencia cultural en Latinoamérica. Chasqui: Revista Latinoamericana de Comunicación 131: 47-63.

Lozano, José Carlos. 2007. Latin America: Media Conglomerates. In The Media Globe: Trends in International Mass Media, edited by Lee Artz and Yahyar R. Kamalipour, 99118. Plymouth: Rowman \& Littlefield.

Maldonado, Efendy. 2015. Epistemología de la comunicación: Análisis de la vertiente Mattelart en América Latina. Quito: CIESPAL.

Marques de Melo, José. 1984. La investigación latinoamericana en comunicación. Chasqui: Revista Latinoamericana de Comunicación 11: 4-11.

Martín-Barbero, Jesús. 2002a. Communications: Decentering Modernity. In Latin America Writes Back: Posmodernity in the Periphery, edited by Emil Volek, 39-58. London: Routledge.

Martín-Barbero, Jesús. 2002b. La globalización en clave cultural: Una mirada a América Latina. Paper presented at the Conference on Globalism and Plurality, Montreal, 24-27 April.

Martín-Barbero, Jesús. 1993. Communication, Culture and Hegemony: From the Media to Mediations. London: Sage.

Martín-Barbero, Jesús and Armando Silva, eds. 1998. Proyectar la comunicación. Bogota: Tercer Mundo. 
Mattelart, Armand. 2010. An Archaeology of the Global Era: Constructing a Belief. In International Communication: A Reader, edited by Daya K. Thussu, 313-328. London: Routledge.

Mattelart, Armand. 1999. Prólogo. In Economía política, comunicación y conocimiento, edited by César Bolaño, 7-16. Tucuman: La Crujía.

Mattelart, Armand and Michele Mattelart. 2005. Historia de las teorías de la comunicación. Barcelona: Paidos.

McChesney, Robert W. 2007. The Political Economy of Media: Enduring Issues, Emerging Dilemmas. New York: Monthly Review Press.

McChesney, Robert W. 2000. Rich Media, Poor Democracy: Communication Politics in Dubious Times. New York: The New Press.

McQuail, Denis. 2005. Mass Communication Theory. London: Sage.

Merino, José. 2007. No Such Thing as a Social Advantage for the Left? In Leftovers: Tales of the Latin American Left, edited by Jorge G. Castañeda and Marco A. Morales, 66-91. New York: Routledge.

Moffitt, Benjamin and Simon Tormey. 2014. Rethinking Populism: Politics, Mediatization and Political Style. Political Studies 62 (2): 381-397.

Moffitt, Benjamin. 2016. The Global Rise of Populism: Performance, Style, and Representation. Stanford: Stanford University Press.

Morelock, Jeremiah, ed. 2018. Critical Theory and Authoritarian Populism. London: University of Westminster Press.

Mosco, Vincent. 2006. Revisiting the Political Economy of Communication. In Marxism and Communication Studies: The Point is to Change It, edited by Lee Artz, Steve Macek and Dana L. Cloud, 87-110. New York: Peter Lang.

Mouffe, Chantal. 2018. For a Left Populism. London: Verso.

Mudde, Cas and Cristóbal Rovira Kattwasser. 2013. Exclusionary vs. Inclusionary Populism: Comparing Contemporary Europe and Latin America. Government and Opposition 48 (2): 147-174.

Mudde, Cas and Cristóbal Rovira Kattwasser, eds. 2012. Populism in Europe and the Americas: Threat or Corrective to Democracy? Cambridge: Cambridge University Press.

Murphy, Patrick D. and Clemencia Rodríguez. 2006. Between Macondo and McWorld: Communication and Culture Studies in Latin America. Global Media and Communication 2 (3): 267-277.

Fuentes-Navarro, Raúl. 1999. La investigación de la comunicación en América Latina: Condiciones y perspectivas para el siglo XXI. Comunicación y Sociedad 36: 105-132.

Fuentes-Navarro, Raúl. 1991. Un campo cargado de futuro: El estudio de la comunicación en América Latina. Guadalajara: ITESO.

Orozco, Guillermo. 2008. La 'mediación' de Jesus Martín-Barbero. Anthropos 219: 136-138.

Orozco, Guillermo. 2002. Recepción y mediaciones: Casos de investigación en América Latina. Buenos Aires: Norma.

Osorio Tejeda, Nelson. 2007. Estudios latinoamericanos y nueva dependencia cultural. Revista de crítica literaria latinoamericana 66: 251-278.

Panizza, Francisco. 2005. Populism and the Mirror of Democracy. London: Verso.

Pasquali, Antonio. 2007. Comprender la comunicación. Caracas: Monte Avila.

Pedro-Carañana, Joan. 2020. Towards a Marxist Theory of Mediation: Contributions from Ibero-America to the Study of Digital Communication. tripleC: Communication, Capitalism \& Critique 18 (1): 236-253. https://doi.org/10.31269/triplec.v18i1.1129

Prieto-Castillo, Daniel. 2019. Investigación y obra pedagógica en el campo de la comunicación. Chasqui: Revista Latinoamericana de Comunicación 141: 33-48.

Reid, Michael. 2009. Forgotten Continent: The Battle for Latin America's Soul. New Haven: Yale University Press. 
Retamozo, Martín. 2016. La teoría política del populismo: Usos y controversias en América Latina en la perspectiva posfundacional. Latinoamérica: Revista de Estudios Latinoamericanos 64: 125-151.

Retamozo, Martín. 2006. Populismo y teoría política: De una teoría hacia una epistemología del populismo para América Latina. Revista Venezolana de Economía y Ciencias Sociales 12 (2): 95-113.

Roblas Martín, Sara. 2012. Globalización y medios de comunicación: Carencias sociales de los efectos económicos. Cuadernos de Información y Comunicación 17: 303-320.

Rovira Kattwasser, Cristóbal. 2018. Is Latin America Facing a Wave of Right-Wing Populism? Prague: Project Syndicate.

Sarlo, Beatriz. 2001. Tiempo presente: Notas sobre el cambio de una cultura. Buenos Aires: Siglo Veintiuno.

Schamis, Hector E. 2006. Populism, Socialism, and Democratic Institutions. Journal of Democracy 17 (4): 20-34.

Schiller, Herbert I. 1991. Not Yet the Post-Imperialist Era. Critical Studies in Mass Communication 8 (1): 13-28.

Schlesinger, Philip. 1993. Introduction. In Communication, Culture and Hegemony: From the Media to Mediations, edited by Jesús Martín-Barbero, 11-19. London: Sage.

Seligson, Mitchell A. 2007. The Rise of Populism and the Left in Latin America. Journal of Democracy 18 (3): 81-95.

Sengul, Kurt. 2019. Populism, Democracy, Political Style and Post-Truth: Issues for Communication Research. Communication Research and Practice 5 (1): 1-14.

Sparks, Colin. 2007. Globalization, Development and the Mass Media. London: Sage.

Straubhaar, Joseph. 2015. Global, Regional, Transnational, Translocal. Media Industries Journal 1 (3): 48-53.

Straubhaar, Joseph. 1991. Beyond Media Imperialism: Assymetrical Interdependence and Cultural Proximity. Critical Studies in Mass Communication 8 (1): 39-59.

Szurmuk, Mónica and Silvio R. Waisbord. 2011. The Intellectual Impasse of Cultural Studies of the Media in Latin America. Westminster Papers in Communication and Culture 8 (1): 7-32.

Taggart, Paul. 2004. Populism and Representative Politics in Contemporary Europe. Journal of Political Ideologies 9 (3): 269-288.

Thussu, Daya K. 2000. International Communication: Continuity and Change. London: Arnold.

Tomlinson, John. 1999. Globalization and Culture. Cambridge: Polity.

Vassallo de Lopes, Maria Immacolata. 2014. Mediation and Reception. Some Theoretical and Methodological Connections in Latin American Communication Studies. MATRIZes 8 (1): 1-18.

Vassallo de Lopes, Maria Immacolata. 2018. The Barberian Theory of Communication. MATRIZes 12 (1): 39-63.

Villacañas, José Luis. 2015. Populism. Madrid: La Huerta Grande.

Vinelli, Natalia, 2014. La televisión desde abajo: Historia, alternatividad y periodismo de contrainformación. Buenos Aires: Cooperativa El Río Suena.

Waisbord, Silvio. 2013a. Reinventing Professionalism: Journalism and News in Global Perspective. Cambridge: Polity Press.

Waisbord, Silvio. 2013b. Media Policies and the Blind Spots of Media Globalization: Insights from Latin America. Media, Culture \& Society 35 (1): 132-138.

Waisbord, Silvio. 2012. Democracy, Journalism, and Latin American Populism. Journalism, 14 (4): 504-521.

Waisbord, Silvio. 2011. Between Support and Confrontation: Civil Society, Media Reform, and Populism in Latin America. Communication, Culture \& Critique 4 (1): 97-117. 
Waisbord, Silvio. 2000. Media in South America: Between the Rock of the State and the Hard Place of the Market. In De-Westernizing Media Studies, edited by James Curran and Myung-Jin Park, 50-62. London: Routledge.

Weyland, Kurt. 2001. Clarifying a Contested Concept: Populism in the Study of Latin American Politics. Comparative Politics 34 (1): 1-22.

White, Robert A. 1989. La teoría de la comunicación en América Latina: Una visión europea de sus contribuciones. Telos 19: 43-54.

Wortham, Erica Cusi. 2004. Between the State and Indigenous Autonomy: Unpacking Video Indígena in Mexico. American Anthropologist 106 (2): 363-368.

\begin{abstract}
About the author
Edmundo Bracho-Polanco

Dr Edmundo Bracho-Polanco received his MA in International Journalism at Cardiff University and his PhD in Media and Communication at the University of Westminster. He is a member of the Communication and Media Research Institute and a Lecturer in Journalism and Media at the University of Westminster. He is a strategy consultant for the Media Diversity Institute, UK. His research and teaching focuses on media and democracy, the sociology of media and journalism, and popular culture.
\end{abstract}

